\title{
Identification of the Spatial Variability of Runoff Coefficients of Three Wet Zone Watersheds of Sri Lanka
}

\author{
K. R. J. Perera and N. T. S. Wijesekera
}

\begin{abstract}
Runoff estimation from rainfall records in the absence of stream gauge records is essential in Sri Lanka, because most of the watersheds are ungauged. Since runoff depends on the catchment characteristics in addition to the rainfall, this study focuses on streamflow determination as a function of land use, soil and slope from developed GIS model. This study developed a method to estimate runoff coefficient as a function of land use, soil and slope within the wet zone basins of Sri Lanka.
\end{abstract}

Three Wet Zone basins, Kalu Ganga, Kelani Ganga and Attanagalu Oya were selected for the study. Regression analysis showed that the computed runoff agreed with the observed runoff with $\mathrm{R}^{2}$ values of 0.80, 0.78 and 0.83 for Kalu Ganga, Kelani Ganga and Attanagalu Oya basin respectively. Averaged runoff coefficients, for basins with the spatial variation were calculated as $0.52,0.49$ and 0.51 for Kelani Ganga, Kalu Ganga and Attanagalu Oya sub basin respectively. Study revealed that credible runoff coefficient will not be represented simply by the ratio between runoff and rainfall where runoff depends highly on catchment characteristics.

Keywords: Spatial variability, GIS (Geographic Information Systems), river basin planning, runoff, catchment characteristics.

\section{Introduction}

Estimating runoff from rainfall records in the absence of stream gauge records is extremely important in water resources development. It is more so in Sri Lanka where most of the watersheds are ungauged. Runoff coefficients enable the estimation of runoff for practical applications such as water resource management and river basin planning.

Catchment specific studies have been carried out all over the world. Moreover, rainfall runoff models have been developed over several decades. Abulohom et al. [1] have developed a rainfall runoff model based on water balance equations where inputs to the model include precipitation and potential evapotranspiration on monthly basis which in turn give simulated runoff at watershed outlet. De Smedt et al. [6] have developed a physically based distributed hydrological model which simulates the hydrologic behavior and runoff in a river basin where the model has been validated on a small watershed in Belgium. Naden [11] presented spatially distributed rainfall-runoff model which included hillslope, network width, and routing as functions which were finally combined to find overall catchment response function. Kumar and Sathish [8] and Agarwal and Singh [2] have utilized Artificial Neural Networks, Recurrent Neural Networks for runoff modelling and river flow forecasting. Liu et al. $[9,10]$ also have performed a study on storm runoff prediction from different land use classes using GIS-based distributed model.

Runoff is governed by many factors in addition to rainfall. It has been known that land use, soil type and slope are the primary catchment characteristics that govern runoff and hence runoff coefficient [6]. Determining runoff coefficient and its variation with the major parameters is important for water resources assessments giving due consideration to the soil, slope and land use variations.

Eng. (Dr.) (Mrs.) K.R.J.Perera, B.Sc. Eng. (Moratuwa), M.Phil. (Moratuwa), MS(USA), Ph.D. (USA), AMIE(Sri Lanka), College Assistant Professor of Civil Engineering, Department of Civil Engineering, New Mexico State University, NM, USA.

Eng. (Prof.) N.T.S.Wijesekera, B.Sc. Eng. (Sri Lanka),

C. Eng., FIE(Sri Lanka), MICE(UK), PG Dip Hyd

Structures (Moratuwa), M. Eng. (Tokyo), D. Eng. (Tokyo). Senior Professor of Civil Engineering, Department of Civil Engineering, University of Moratuwa, Sri Lanka. 


\section{Study Area}

Attanagalu Oya basin at Karasnagala gauging station (Attanagalu Oya sub basin), Kelani Ganga at Glencourse gauging station (Kelani Ganga sub basin) and Kalu Ganga at Putupaula gauging station (Kalu Ganga sub basin) were selected as study areas of this study. Details of these sub basins are given below.

\subsection{Attanagalu Oya basin at Karasnagala (Attanagalu Oya sub basin)}

Attanagalu Oya is located in the wet zone of Sri Lanka between the latitudes $7^{\circ} 00^{\prime}$ and $7^{\circ} 17^{\prime} \mathrm{N}$, Longitudes $79^{\circ} 50^{\prime}$ and $80^{\circ} 15^{\prime} \mathrm{E}$. Total catchment area at Kotugoda is $539 \mathrm{~km}^{2}$. It contains eleven secretariat divisions in the Gampaha and Kegalle administrative districts of Western and Sabaragamuwa provinces respectively. Figure 1 shows the stream network of the sub catchment of Attanagalu Oya basin at Karasnagala stream gauging point (Attanagalu Oya sub basin).

Two rainfall gauging stations were selected (Karasnagala- within the basin boundary and Vincit- just outside the boundary) to cover the study area.
In addition, a streamflow gauging station maintained at Karasnagala by the Irrigation Department of Sri Lanka is the only available stream gauging station (non-recording) at Karasnagala. Stream gauging station had a recorder at Karasnagala, which is not functioning at present. The details of this station were verified by personal consultation and through field visits.

\subsection{Kelani Ganga basin at Glencourse (Kelani Ganga sub basin)}

Kelani Ganga basin is located in the wet zone of Sri Lanka between the latitudes $6^{\circ} 45^{\prime}$ and $7^{\circ} 15^{\prime}$ $\mathrm{N}$, Longitudes $79^{\circ} 50^{\prime}$ and $80^{\circ} 45^{\prime} \mathrm{E}$. Sub basin of the Kelani Ganga at Glencourse was selected for this study. Total catchment area is about $1537 \mathrm{~km}^{2}$ at Glencourse (Kelani Ganga sub basin). Data from six rainfall gauging stations and one streamflow gauging were available for the study. Figure 2 shows the stream network and hydro-meteorology network of the Kelani Ganga basin at Glencourse which is the selected catchment outlet.

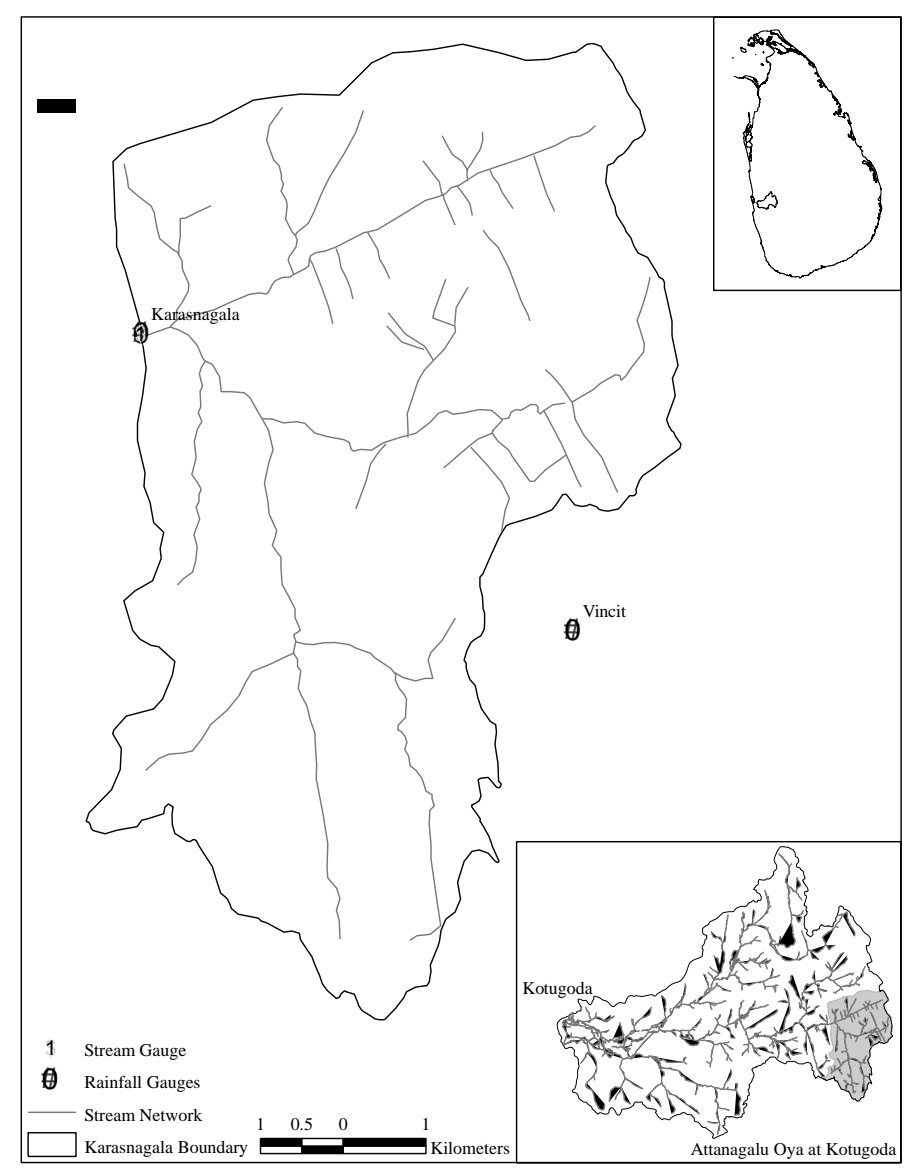

Figure 1 - Attanagalu Oya catchment at Karasnagala gauging point 


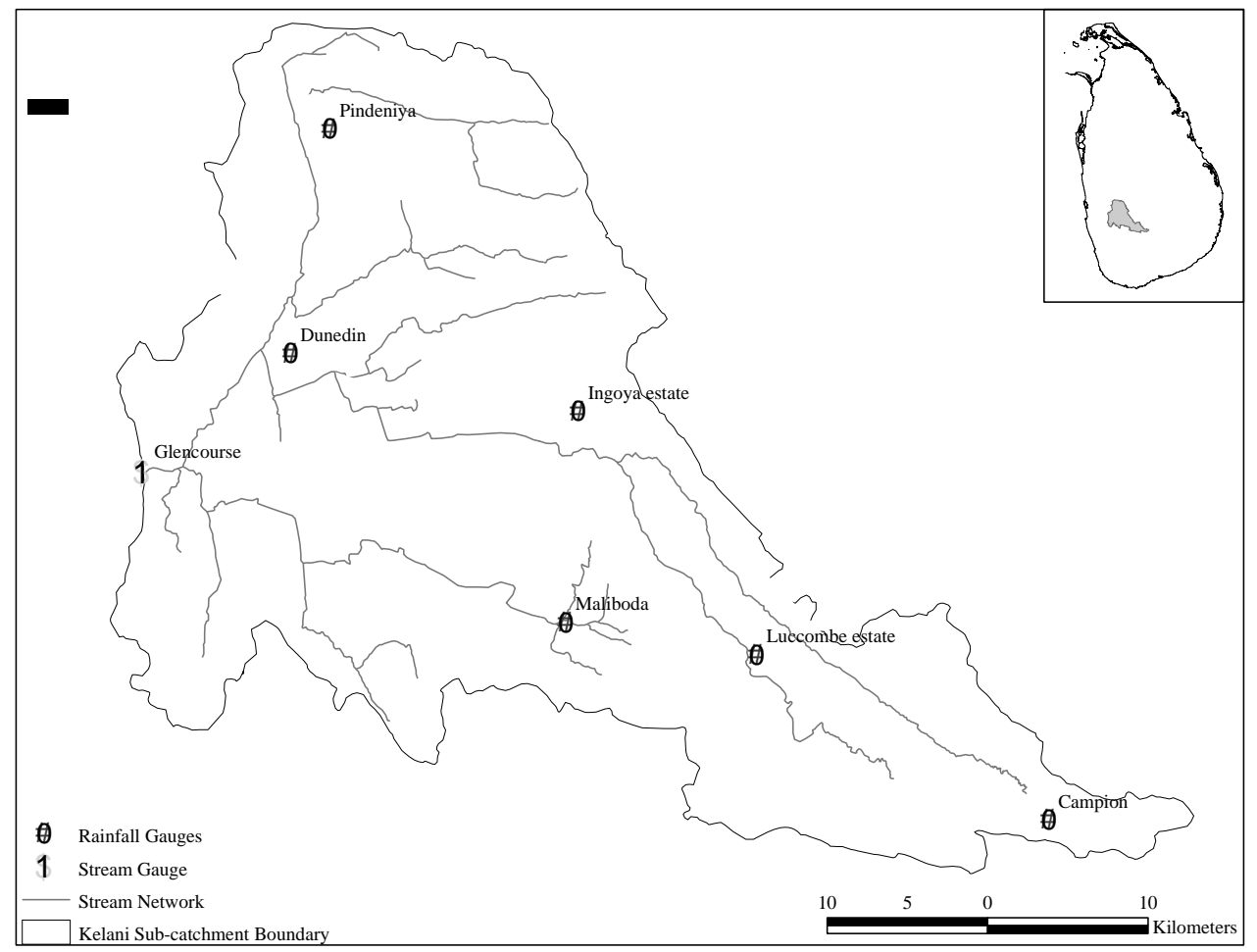

Figure 2 - Stream network and hydro-meteorology network of the Kelani Ganga basin

\subsection{Kalu Ganga basin at Putupaula (Kalu} Ganga sub basin)

Kalu Ganga basin is located in the wet zone of Sri Lanka between the latitudes $6^{\circ} 20^{\prime}$ and $6^{\circ} 55^{\prime}$ $\mathrm{N}$, Longitudes $79^{\circ} 55^{\prime}$ and $80^{\circ} 45^{\prime} \mathrm{E}$. Sub basin of the Kalu Ganga at Putupaula was selected for this study.
Total catchment area is about $2627 \mathrm{~km}^{2}$ at Putupaula (Kalu Ganga sub basin). Data of seven rainfall gauging stations and one streamflow gauging station were available for the study. Figure 3 shows the stream network and hydro-meteorology network of the Kalu Ganga basin at the Putupaula gauging station.

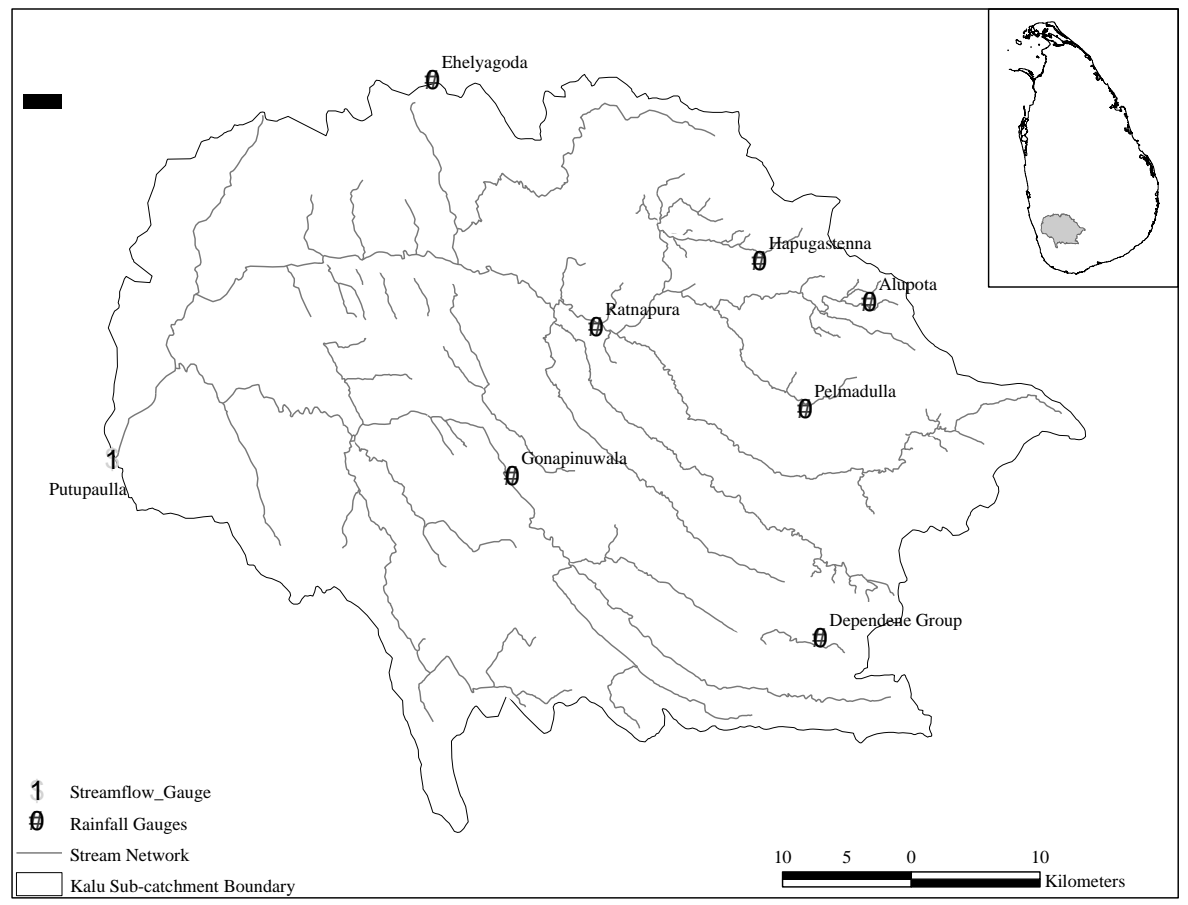

Figure 3 - Stream network and hydro-meteorology network of the Kalu Ganga basin at Putupaula gauging station 


\section{Data and Methodology}

Rainfall, streamflow, land use, soil and slope data were collected (Table 1a - Table 4). Collected data were checked for consistency and compatibility. Visual examination, annual water balance, Double Mass Curve method and statistical checks for homogeneity were used.
Field visits were carried out for data collection and verification. Tables 1a) and 1b) show the rainfall and streamflow data availability and the selected data for the study.

Table 1a) - Rainfall data availability within basins

\begin{tabular}{|c|c|c|c|}
\hline Basin Name & Station Name & $\begin{array}{l}\text { Period of } \\
\text { Availability } \\
\end{array}$ & $\begin{array}{l}\text { Selected } \\
\text { Data Set }\end{array}$ \\
\hline \multirow{5}{*}{$\begin{array}{l}\text { Kelani ganga basin } \\
\text { at Glencourse* }\end{array}$} & Campion & 1943-85 & $1950-70$ \\
\hline & Dunedin & 1949-85 & $1950-70$ \\
\hline & Ingoya Estate & 1949-85 & $1950-70$ \\
\hline & Luccombe Estate & 1943-76 & $1950-70$ \\
\hline & Pindeniya & 1949-73 & $1950-70$ \\
\hline \multirow{7}{*}{$\begin{array}{l}\text { Kalu ganga basin } \\
\text { at Putupaulla* }\end{array}$} & Alupota & 1949-85 & $1950-70$ \\
\hline & Dependene Group & 1949-85 & $1950-70$ \\
\hline & Eheliyagoda & 1949-85 & $1950-70$ \\
\hline & Gonapinuwala & 1949-84 & $1950-70$ \\
\hline & Hapugastenna & 1949-85 & $1950-70$ \\
\hline & Pelmadulla & 1949-84 & $1950-70$ \\
\hline & Ratnapura & 1949-85 & $1950-70$ \\
\hline \multirow{2}{*}{$\begin{array}{l}\text { Attanagalu Oya basin } \\
\text { at Karasnagala** } \dagger\end{array}$} & Karasnagala & Continuous & 1971-80 \\
\hline & Vincity & 1925/09-to Date & 1971-81 \\
\hline \multicolumn{4}{|l|}{$\begin{array}{r}\text { Sources: } \\
* \\
\dagger\end{array}$} \\
\hline
\end{tabular}

Table 1b) - Streamflow data availability within basins

\begin{tabular}{|l|l|l|l|}
\hline Basin Name & Station Name & $\begin{array}{l}\text { Period of } \\
\text { Availability }\end{array}$ & $\begin{array}{l}\text { Selected } \\
\text { Data Set }\end{array}$ \\
\hline Kelani ganga* $^{*}$ & Glencourse & $1948-85$ & $1950-70$ \\
\hline Kalu ganga* & Putupaula & $1943-85$ & $1950-70$ \\
\hline Attanagalu Oya** & Karasnagala & Continuous & $1971-80$ \\
\hline
\end{tabular}

Table 2 - Land use data for three sub basins.

\begin{tabular}{|l|r|r|r|r|r|r|}
\hline & \multicolumn{2}{|c|}{$\begin{array}{c}\text { Attanagalu Oya sub } \\
\text { Kasin at } \\
\text { Karasnagala }\end{array}$} & \multicolumn{2}{|c|}{$\begin{array}{l}\text { Kelani Ganga sub } \\
\text { basin at Glencourse }\end{array}$} & \multicolumn{2}{c|}{$\begin{array}{l}\text { Kalu Ganga sub basin } \\
\text { at Putupaula }\end{array}$} \\
\hline Land Use Type & $\begin{array}{l}\text { Area } \\
\left(\mathrm{km}^{2}\right)\end{array}$ & $\begin{array}{l}\text { Percentage } \\
\text { of Area }(\%)\end{array}$ & $\begin{array}{l}\text { Area } \\
\left(\mathrm{km}^{2}\right)\end{array}$ & $\begin{array}{l}\text { Percentage } \\
\text { of Area (\%) }\end{array}$ & $\begin{array}{l}\text { Area } \\
\left(\mathrm{km}^{2}\right)\end{array}$ & $\begin{array}{l}\text { Percentage } \\
\text { of Area }(\%)\end{array}$ \\
\hline Cultivation & 38.96 & 72.82 & 944.76 & 61.46 & 1470.85 & 55.98 \\
\hline Forest & 1.20 & 2.25 & 297.96 & 19.38 & 616.87 & 23.48 \\
\hline Garden & 7.76 & 14.50 & 214.70 & 13.97 & 90.82 & 3.46 \\
\hline $\begin{array}{l}\text { Grass and } \\
\text { Chena }\end{array}$ & 5.14 & 9.61 & 59.54 & 3.87 & 448.85 & 17.08 \\
\hline $\begin{array}{l}\text { Rock, Tanks } \\
\text { and Reservoirs }\end{array}$ & 0.44 & 0.82 & 20.12 & 1.31 & 0.02 & 0.00 \\
\hline
\end{tabular}


Table 3 - Soil data for three sub basins

\begin{tabular}{|c|c|c|c|c|c|c|}
\hline \multirow[t]{2}{*}{ Soil Type } & \multicolumn{2}{|c|}{$\begin{array}{l}\text { Attanagalu Oya sub } \\
\text { basin at Karasnagala }\end{array}$} & \multicolumn{2}{|c|}{$\begin{array}{c}\text { Kelani Ganga sub } \\
\text { basin at Glencourse }\end{array}$} & \multicolumn{2}{|c|}{$\begin{array}{c}\text { Kalu Ganga sub basin } \\
\text { at Putupaula }\end{array}$} \\
\hline & $\begin{array}{l}\text { Area } \\
\left(\mathbf{k m}^{2}\right)\end{array}$ & $\begin{array}{l}\text { Percentage } \\
\text { of Area }(\%)\end{array}$ & $\begin{array}{l}\text { Area } \\
\left(\mathbf{k m}^{2}\right)\end{array}$ & $\begin{array}{l}\text { Percentage } \\
\text { of Area }(\%)\end{array}$ & $\begin{array}{l}\text { Area } \\
\left(\mathrm{km}^{2}\right)\end{array}$ & $\begin{array}{l}\text { Percentage } \\
\text { of Area }(\%)\end{array}$ \\
\hline RYP & 52.79 & 98.71 & 1387.77 & 90.29 & 2468.92 & 93.97 \\
\hline Alluvial & 0.69 & 1.29 & 130.57 & 8.50 & 117.44 & 4.47 \\
\hline Rockland \& Lithosols & - & - & 18.74 & 1.22 & - & 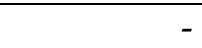 \\
\hline Bog \&Half Bog Soils & - & - & - & - & 13.91 & 0.53 \\
\hline
\end{tabular}

Table 4 - Slope class classification

\begin{tabular}{|c|c|}
\hline Slope (\%) & Slope Class \\
\hline $0-2 \%$ & Flat \\
\hline $2-7 \%$ & Average \\
\hline$>7 \%$ & Steep \\
\hline
\end{tabular}

Source: Andy and Stanley [3].

Twenty years of monthly rainfall data were used in the analysis of Kelani Ganga and Kalu Ganga basins while ten years data were used in Attanagalu Oya basin as indicated in Tables 1 a) and 1 b). For Kelani and Kalu sub catchments rainfall runoff data from 1950-1970 and for Attanagalu Oya sub catchment, data from 1970-1980 were employed. Rainfall data were used to calculate runoff with the assumed runoff coefficients. Initial values of Runoff coefficients were identified from literature survey $[3,4,5,7]$.

Land use, soil and slope soft copy data were obtained from Survey Department of Sri Lanka which was digitized from 1:50,000 topo-sheets. Land use of the catchment was classified into five groups; soil into two; and slope into three. There were two major soil types in each catchment and therefore two classes were considered. Kalu Ganga sub basin has Red Yellow Podzolic and Alluvial soils as the main soil types $(>98 \%)$ while two other soil types with less than $2 \%$ of the covered area (Table 3 ). Similar pattern was observed in Kelani Ganga sub basin (Table 3).
Major soil type for Attanagalu Oya sub basin was Red Yellow Podzolic (>98\%). Hence Red Yellow Podzolic soil was considered for the analysis of Attanagalu Oya sub basin.

Spatial variability of runoff coefficients were assessed using a Geographic Information System (GIS). Land use, soil and slope polygon layers (vector format) prepared using GIS and overlay operations, table operations, etc., were used in the analysis. Table 2, Table 3 and Table 4 show the land use, soil variation and slope classification respectively for the three study areas.

Observed streamflow data at Glencource, Putupaula and Karasnagala were used to compare computed runoff. Kelani Ganga data was used first and coefficients were determined by trial and matching with observed data. The model calibration and verification used the Mean Ratio of Absolute Error (MRAE) as the objective function [12, 13]. Model verification and calibration for each watershed was carried out with different datasets. A similar procedure was adapted to the Kalu Ganga basin and the Attanagalu Oya basins to identify the respective parameters. The overall methodology adopted for the study is shown in Figure 4.

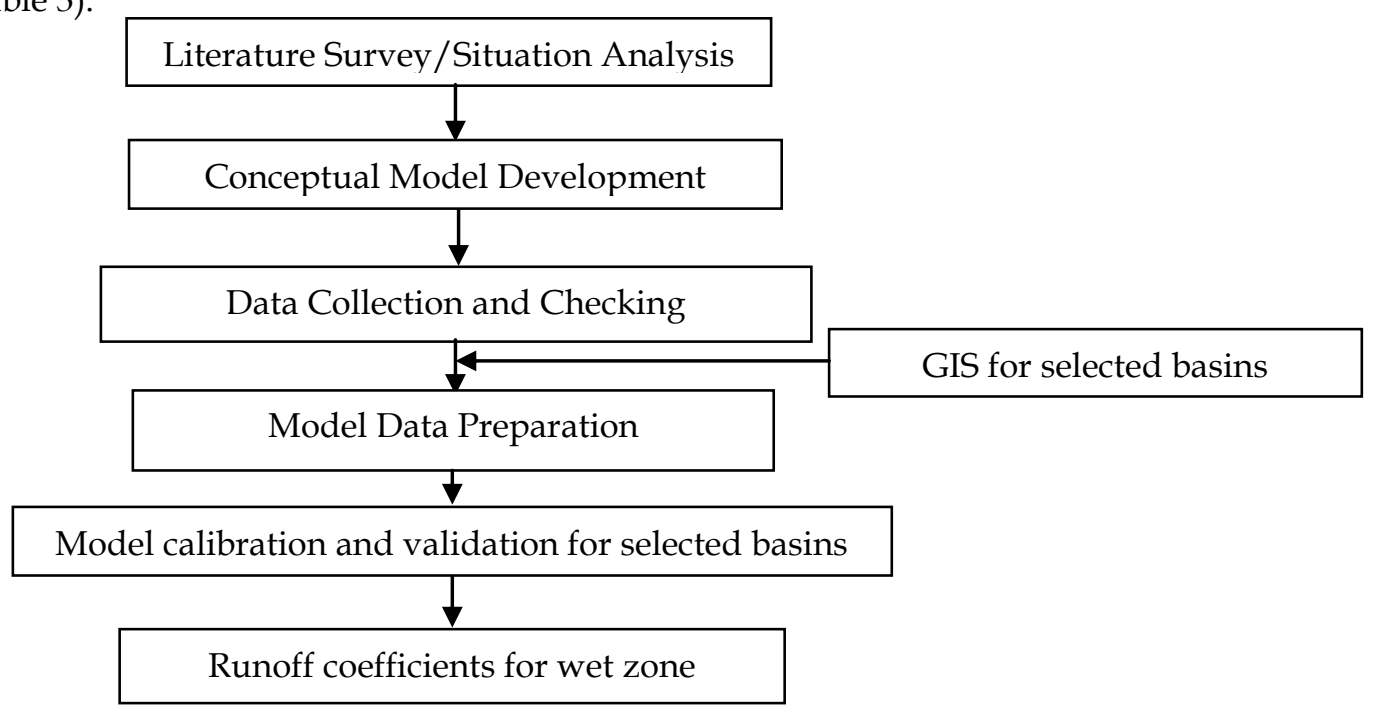


Spatially varied land use, soil and slope data which were collected and identified on maps were digitized using GIS (vector format). Three catchment characteristics for a given basin was overlaid using overlay operation in GIS. This activity creates different land parcels with different catchment characteristics. Required land parcel was selected using table operations for later applications.

\subsection{Model development}

A simple conceptual model was used to compute runoff from each land parcel. The model assumed a linear function incorporating land use, slope and soil as major catchment parameters contributing to convert rainfall into surface runoff.

Surface Runoff $=f($ Runoff Coefficient, Rainfall)

The cumulative runoff contributed from each land parcel in a catchment was taken as the surface runoff generated from the catchment.

Runoff Coefficient $=f($ Land use, Slope, Soil $)$

$\mathrm{Q}=\left(\mathrm{P}_{\mathrm{ijk}}{ }^{*} \mathrm{~A}_{\mathrm{ijk}}\right) * \mathrm{R}$

where,

$\mathrm{R}=$ Rainfall

$\mathrm{A}_{\mathrm{ijk}}=$ Area of concern with given factors $\mathrm{i}, \mathrm{j}, \mathrm{k}$

Coefficient $\mathrm{P}_{\mathrm{ijk}}=f\left(\mathbf{i}_{(1-5)}, \mathrm{j}_{(1-3)}, \mathrm{k}_{(1-2)}\right)$
Table 5 -Land use, slope and soil classification

\begin{tabular}{|l|l|l|l|l|l|}
\hline \multicolumn{2}{|l|}{ Land use (i) } & \multicolumn{2}{l|}{ Slope (j) } & \multicolumn{2}{l|}{ Soil (k) } \\
\hline $\mathbf{i}$ & Class & $\mathbf{j}$ & Class & $\mathbf{k}$ & Class \\
\hline $\mathbf{1}$ & Forest & $\mathbf{1}$ & Flat & $\mathbf{1}$ & $\begin{array}{l}\text { Red } \\
\text { Yellow } \\
\text { Podzolic }\end{array}$ \\
\hline $\mathbf{2}$ & Garden & $\mathbf{2}$ & Average & $\mathbf{2}$ & Alluvial \\
\hline $\mathbf{3}$ & $\begin{array}{l}\text { Grass \& } \\
\text { Chena }\end{array}$ & $\mathbf{3}$ & Steep & \multicolumn{2}{|l}{} \\
\cline { 1 - 2 } $\mathbf{4}$ & Cultivation & \multicolumn{3}{|l}{} \\
\hline $\mathbf{5}$ & $\begin{array}{l}\text { Rocks, } \\
\text { tanks \& } \\
\text { reservoirs }\end{array}$ & \multicolumn{3}{|l}{} \\
\hline
\end{tabular}

$P_{\mathrm{ijk}}$ represents the coefficient for $\mathrm{i}^{\text {th }}$ land use type, $\mathrm{j}^{\text {th }}$ slope class and $\mathrm{k}^{\text {th }}$ soil type where $i$ varies from 1-5, $j$ varies between 1-3 and $k$ from 1-2. For an instance, $P_{231}$ represents the coefficient for steep slope garden areas with red yellow podzolic soil type. Parameters of the model assigned by the above criteria are given in Table 6. Model parameters ( $\mathrm{P}$ values) were estimated (optimized) using Mean Ratio of Absolute Error as the objective function [12, 13]. Parameter optimization was initiated with the literature values $[3,4,5,7]$. Parameters at which minimum MRAE were selected as finalized parameters of the model.

\subsection{Overall runoff coefficient}

In the present work the overall runoff coefficient which is the area weighted runoff coefficient for a particular watershed was computed using equation 4 .

Table 6 - Classification of model parameters on land use, soil and slope

\begin{tabular}{|c|c|c|c|}
\hline \multirow[b]{2}{*}{ Land Use (i) } & \multirow[b]{2}{*}{ Slope Class $(j)$} & \multicolumn{2}{|l|}{ Soil $(k)$} \\
\hline & & $\begin{array}{l}\text { Red } \\
\text { Yellow } \\
\text { Podzolic } \\
\text { (RYP) - (1) }\end{array}$ & $\begin{array}{l}\text { Alluvial } \\
(A L)-(2)\end{array}$ \\
\hline \multirow[t]{3}{*}{ Forest (1) } & Flat (0-2 \%) (1) & $\left(\mathrm{P}_{111}\right)$ & $\left(\mathrm{P}_{112}\right)$ \\
\hline & Average Slope (2-7 \%) (2) & $\left(\mathrm{P}_{121}\right)$ & $\left(\mathrm{P}_{122}\right)$ \\
\hline & Steep Slope (over 7 \%) (3) & $\left(\mathrm{P}_{131}\right)$ & $\left(\mathrm{P}_{132}\right)$ \\
\hline \multirow[t]{3}{*}{ Garden (2) } & Flat $(0-2 \%)$ & $\left(\mathrm{P}_{211}\right)$ & $\left(P_{212}\right)$ \\
\hline & Average Slope (2-7 \%) & $\left(\mathrm{P}_{221}\right)$ & $\left(\mathrm{P}_{222}\right)$ \\
\hline & Steep Slope (over 7 \%) & $\left(\mathrm{P}_{231}\right)$ & $\left(\mathrm{P}_{232}\right)$ \\
\hline \multirow[t]{3}{*}{ Grass \& Chena (3) } & Flat $(0-2 \%)$ & $\left(P_{311}\right)$ & $\left(P_{312}\right)$ \\
\hline & Average Slope (2-7 \%) & $\left(\mathrm{P}_{321}\right)$ & $\left(\mathrm{P}_{322}\right)$ \\
\hline & Steep Slope (over 7 \%) & $\left(P_{331}\right)$ & $\left(P_{332}\right)$ \\
\hline \multirow[t]{3}{*}{ Cultivation (4) } & Flat $(0-2 \%)$ & $\left(\mathrm{P}_{411}\right)$ & $\left(\mathrm{P}_{412}\right)$ \\
\hline & Average Slope $(2-7 \%)$ & $\left(\mathrm{P}_{421}\right)$ & $\left(\mathrm{P}_{422}\right)$ \\
\hline & Steep Slope (over $7 \%$ ) & $\left(\mathrm{P}_{431}\right)$ & $\left(\mathrm{P}_{432}\right)$ \\
\hline Rocks, Tanks \& Reservoirs (5) & Any Slope & \multicolumn{2}{|c|}{$\left(P_{5,1-3,1-2)}\right.$} \\
\hline
\end{tabular}


This runoff coefficient provides the opportunity to compute an aggregated runoff coefficient for a basin to compute a single runoff coefficient incorporating the variation of soil, slope and land use. Using this method overall runoff coefficients were computed for Kelani, Kalu and Attanagalu Oya basins.

Overall Runoff Coefficient $=\frac{\sum\left(P_{i j k} * A_{i j k}\right)}{\sum A_{i j k}}$

where,

$\mathrm{A}_{\mathrm{ijk}}=$ Area of concern with given factors $\mathrm{i}, \mathrm{j}, \mathrm{k}$ Coefficient $\mathrm{P}_{\mathbf{i j k}}=f\left(\mathbf{i}_{(1-5)}, \mathbf{j}_{(1-3)}, \mathrm{k}_{(1-2)}\right)$ and $\mathbf{i}, \mathbf{j}, \mathbf{k}$ are as explained in Table 5.

\section{Results and Discussion}

\subsection{General results for selected watersheds}

Data checks provided agreeable results with minor error records at Karasnagala streamflow data in year 1975. Annual rainfall for three catchments ranged from $2500 \mathrm{~mm}-5000 \mathrm{~mm}$. Typical dry month for the Attanagalu Oya basin is January while for Kelani and Kalu Ganga sub basins, January and February are the dry months.

Average rainfall in each basin and runoff data at stream gauging locations of each basin (Karasnagala, Putupaulla and Glencourse for Attanagalu Oya, Kalu Ganga and Kelani Ganga sub basin respectively) were used and calculated the ratio of runoff between rainfall (catchments' average runoff coefficients). These numbers were found as $0.40,0.72$, and 0.70 for Attanagalu, Kelani and Kalu sub basins respectively. As spatially varied runoff coefficients were found in this study, catchments' average runoff coefficient were found using the established coefficients as explained in section 3.2.
Hence the runoff coefficients with spatial variation were obtained as $0.51,0.52$, and 0.49 for Attanagalu, Kelani and Kalu sub basins respectively.

\subsection{Model parameters and optimized values}

Each basin contributes to different parameters. Parameters of Kelani Ganga basin were optimized first. Table 7 shows the parameters optimized from Kelani Ganga basin.

The optimized parameters from the Kelani Ganga basin were fixed for the Kalu Ganga basin and the rest of the parameters were optimized for the Kalu Ganga basin which are given in Table 8. Similar analysis was carried out for the Attanagalu Oya basin at Karasnagala and the parameters used and optimized are shown in Table 9. Table 10 shows the finalized coefficients from all three basins, in other words the runoff coefficient matrix.

Cultivation contributes higher percentage of land use for all basins. Cultivation includes coconut, rubber, and other cultivation. For the cultivation group optimized runoff coefficients are $0.61,0.57$ and 0.20 for steep, average and flat slopes for red yellow podzolic soils while that for alluvial soils are 0.55 and 0.50 for steep and average slope respectively. Higher amounts of runoff from rainfall was generated in residential areas which was indicated by higher runoff coefficients: $0.65,0.60$, and 0.55 (steep, average and flat slope respectively) for red yellow podzolic soils and 0.56 (steep slope) and 0.52 (average slope) for alluvial soils. Lowest runoff coefficients were obtained for forest areas with alluvial soils ( 0.10 for steep slope and 0.05 for average slope) followed by red yellow podzolic soils $(0.25,0.20$, and 0.10 for steep, average and flat slope respectively).

Table 7 - Land use, soil, slope factors considered in the Kelani sub basin and model finalized values

\begin{tabular}{|l|c|c|c|c|c|}
\hline \multicolumn{2}{|c|}{} & \multicolumn{2}{c|}{ Parameter } & \multicolumn{2}{c|}{$\begin{array}{c}\text { Optimized } \\
\text { Parameter }\end{array}$} \\
\hline Land Use & Slope Class \Soil & RYP & AL & RYP & AL \\
\hline \multirow{2}{*}{ Forest } & Average Slope $(2-7 \%)$ & & & & \\
\cline { 2 - 7 } & Steep Slope (over 7\%) & $\left(\mathrm{P}_{131}\right)$ & & 0.25 & \\
\hline \multirow{2}{*}{ Garden } & Average Slope $(2-7 \%)$ & $\left(\mathrm{P}_{221}\right)$ & $\left(\mathrm{P}_{222}\right)$ & 0.60 & 0.52 \\
\cline { 2 - 7 } & Steep Slope (over 7\%) & $\left(\mathrm{P}_{231}\right)$ & $\left(\mathrm{P}_{232}\right)$ & 0.65 & 0.56 \\
\hline \multirow{2}{*}{ Grass \& Chena } & Average Slope (2-7 \%) & & & & \\
\cline { 2 - 7 } & Steep Slope (over 7\%) & $\left(\mathrm{P}_{331}\right)$ & & 0.55 & \\
\hline \multirow{2}{*}{ Cultivation } & Average Slope (2-7 \%) & $\left(\mathrm{P}_{421}\right)$ & $\left(\mathrm{P}_{422}\right)$ & 0.57 & 0.50 \\
\cline { 2 - 7 } & Steep Slope (over 7\%) & $\left(\mathrm{P}_{431}\right)$ & $\left(\mathrm{P}_{432}\right)$ & 0.61 & 0.55 \\
\hline Rocks, Tanks, Res. & Any Slope & $\left(\mathrm{P}_{5,1-3,1-2}\right)$ & \multicolumn{2}{c|}{1.00} \\
\hline
\end{tabular}


Table 8 - Land use, soil, slope factors considered in the Kalu Ganga sub basin and finalized values with the model

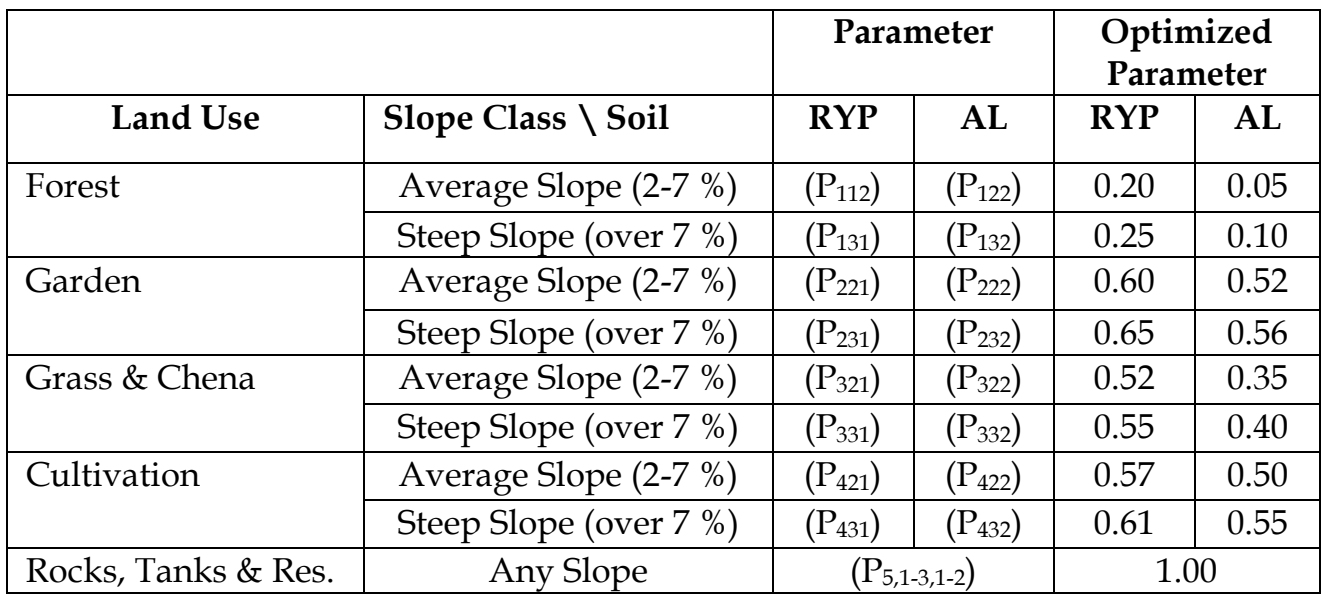

Table 9 - Land use, soil, slope factors considered in the Karasnagala sub basin with optimized values

\begin{tabular}{|l|l|c|c|}
\hline & & Parameter & $\begin{array}{c}\text { Optimized } \\
\text { Parameter }\end{array}$ \\
\hline Land Use & Slope Class \Soil & RYP & \\
\hline \multirow{2}{*}{ Forest } & Flat $(0-2 \%)$ & $\left(\mathrm{P}_{111}\right)$ & 0.10 \\
\cline { 2 - 3 } & Steep Slope (over 7\%) & $\left(\mathrm{P}_{131}\right)$ & 0.25 \\
\hline \multirow{2}{*}{ Grasden } & Flat $(0-2 \%)$ & $\left(\mathrm{P}_{211}\right)$ & 0.55 \\
\cline { 2 - 3 } & Steep Slope (over 7\%) & $\left(\mathrm{P}_{231}\right)$ & 0.65 \\
\hline Cultivation & Flat (0-2 \%) & $\left(\mathrm{P}_{311}\right)$ & 0.45 \\
\cline { 2 - 3 } & Steep Slope (over 7\%) & $\left(\mathrm{P}_{331}\right)$ & 0.55 \\
\hline Rocks, Tanks \& Res. & Flat (0-2 \%) & $\left(\mathrm{P}_{411}\right)$ & 0.20 \\
\cline { 2 - 3 } & Steep Slope (over 7 \%) & $\left(\mathrm{P}_{431}\right)$ & 0.61 \\
\hline
\end{tabular}

Table 10 - Finalized Runoff Coefficient Matrix

\begin{tabular}{|l|l|c|c|}
\hline Land Use & Slope Class \Soil & RYP & AL \\
\hline \multirow{5}{*}{ Forest } & Flat (0-2 \%) & 0.10 & \\
\cline { 2 - 4 } & Average Slope (2-7 \%) & 0.20 & 0.05 \\
\cline { 2 - 4 } & Steep Slope (over 7 \%) & 0.25 & 0.10 \\
\hline \multirow{5}{*}{ Garden } & Flat (0-2 \%) & 0.55 & \\
\cline { 2 - 4 } & Average Slope (2-7 \%) & 0.60 & 0.52 \\
\cline { 2 - 4 } & Steep Slope (over 7 \%) & 0.65 & 0.56 \\
\hline \multirow{5}{*}{ Grass \& Chena } & Flat (0-2 \%) & 0.45 & \\
\cline { 2 - 4 } & Average Slope (2-7 \%) & 0.52 & 0.35 \\
\cline { 2 - 4 } & Steep Slope (over 7 \%) & 0.55 & 0.40 \\
\hline \multirow{5}{*}{ Cultivation } & Flat (0-2 \%) & 0.20 & 0.50 \\
\cline { 2 - 4 } & Average Slope (2-7 \%) & 0.57 & 0.55 \\
\cline { 2 - 4 } & Steep Slope (over 7 \%) & 0.61 & \\
\hline \multicolumn{2}{|c|}{ Any Slope } & 1.00 \\
\hline
\end{tabular}




\subsection{Calculated vs. observed results}

The predictive ability of this approach is demonstrated by comparing calculated streamflows against the observed values. Linear regression analysis was carried out with MRAE (objective function) which was used as the measure of the quality of prediction. MRAE of 0.9 and $\mathrm{R}^{2} 0.83$ for Attanagalu Oya sub basin was obtained (Figure 5). For Kelani Ganga sub basin, MRAE was 0.3 and $\mathrm{R}^{2}$ was 0.78 while MRAE for Kalu Ganga sub basin was 0.44 with $\mathrm{R}^{2}$ of 0.80 (Figure 6, Figure 7 respectively). When compared with the objective function, Kelani Ganaga sub basin provided the best fit among three basins.

Overall runoff coefficients, for basins with the spatial variation were calculated as 0.52, 0.49 and 0.51 for Kelani, Kalu and Attanagalu sub basins, respectively.

Data from five year period (1971-1975) was selected for calibration of Attanagalu Oya sub basin while data from different five years (19761980) was used for validation of the model. Figure 5 shows the agreement between modeled and observed streamflow values.

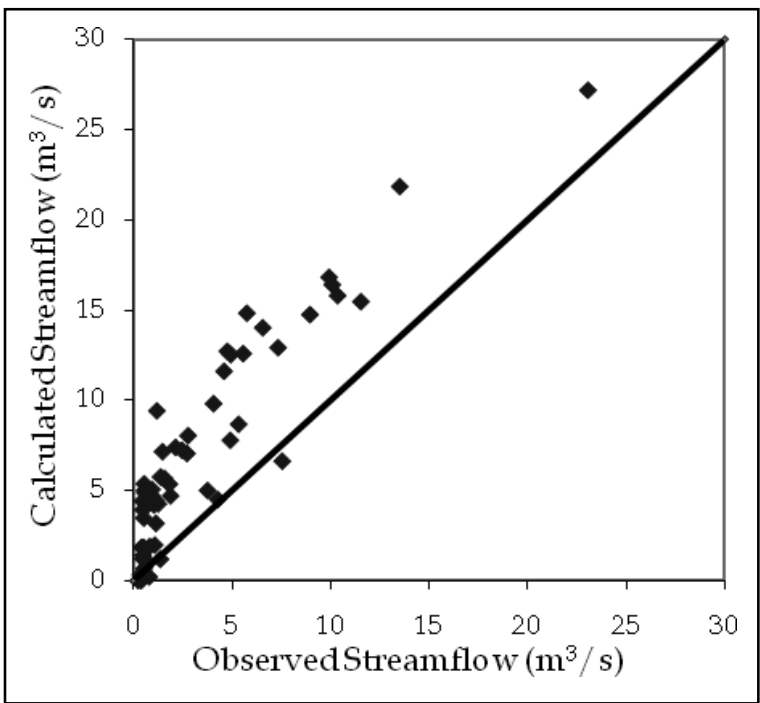

Figure 5 - Calculated Vs observed streamflows for Karasnagala sub basin

The plot in Figure 5 for Attanagalu Oya sub basin (at Karasnagala), indicates an overestimation of the streamflow. As mentioned in methodology and data section, gauging station at Karasnagala was not functioning properly due to clogging by sand where the observed data are undervalued.

Figure 6 shows the quality of fit between calculated and observed streamflow values from model calibration (1951-1960) in Kelani
Ganga sub basin. Data from years 1961-1970 was used for model validation. Even though the $\mathrm{R}^{2}$ value is lower compared to the other two basins, best relationship could be observed in Kelani Ganga sub basin data set with low MRAE (Figure 6).

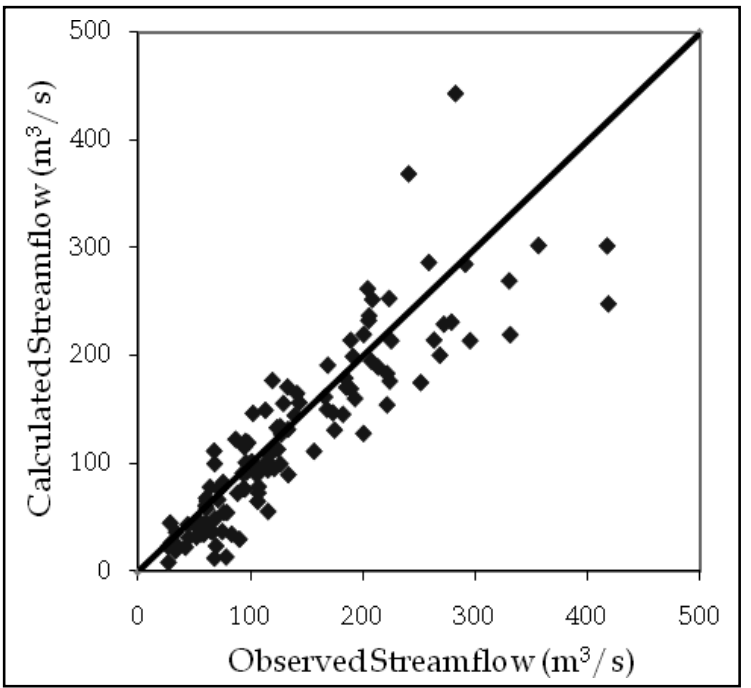

Figure 6 - Calculated Vs observed streamflows for Kelani sub basin

The agreement between the model and the observed streamflow for Kalu Ganga sub basin is shown in Figure 7. Data from 1950-1960 was used for calibration while 1961-1970 used for validation of the model. An underestimation is observed in Kalu Ganga sub basin. Kalu Ganga sub basin land use is cultivation and it receives higher rainfall compared to other two basins of consideration. Overall quality of fit plotted for all three sub basins is shown in Figure 8.

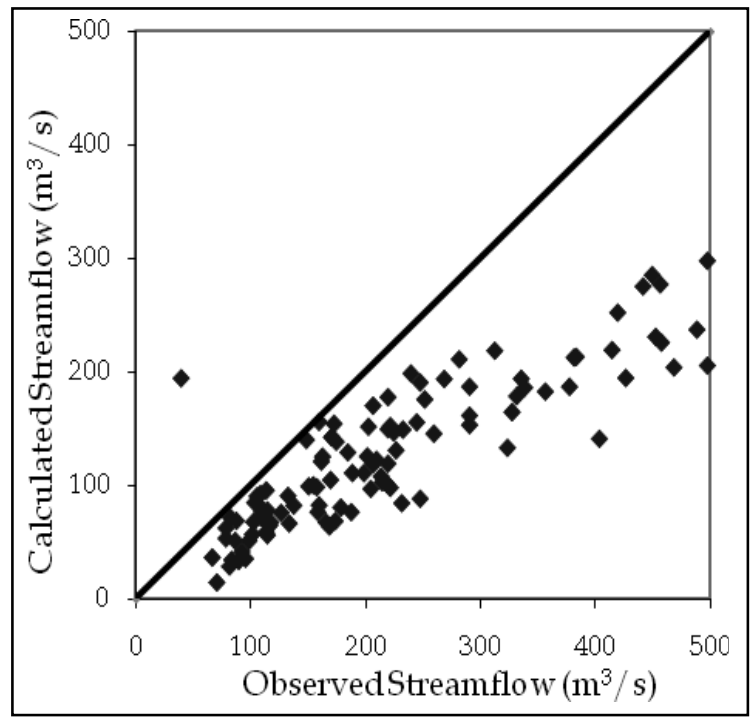

Figure 7 - Calculated Vs observed streamflows for Kalu Ganga sub basin 


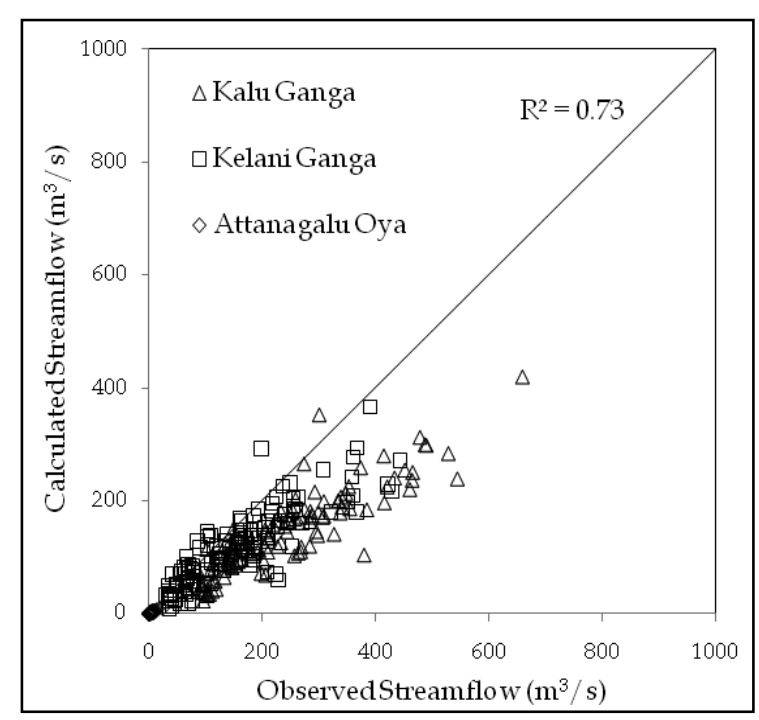

Figure 8 - Overall quality of fit for three sub basins

\section{Conclusions}

A simple conceptual model was developed in this study to estimate runoff from catchment characteristics and rainfall data. Model agreed well with observed data (MRAE values of 0.44 , 0.30 and 0.90 for Kalu Ganga sub basin, Kelani Ganga sub basin and Attanagalu Oya sub basin respectively) with overall $R^{2}$ of 0.73 .

Overall basin averaged runoff coefficients calculated in this study are 0.52, 0.49 and 0.51 for Kelani Ganga sub basin, Kalu Ganga sub basin, and Attanagalu sub basin, respectively. Garden, cultivation, grass \& chena and forests contribute to runoff in decreasing sequence with selected slope or soil type.

\section{Acknowledgement}

This research was supported by University of Moratuwa Senate Research Grant Number 202. Encouragement given by the University of Moratuwa and the Senate Research Committee is gratefully acknowledged.

\section{References}

1. Abulohom, M., Shah, S., Ghumman, R., "Development of a Rainfall-Runoff Model, its Calibration and Validation". Journal of Water Resources Management, 2001, pp.149-163.

2. Agarwal, A., Singh, R., "Runoff Modelling Trough back Propergation Artificial Neural Network with Variable Rainfall Runoff Data". Journal of Water Resources Management, 2004, pp. 285-300.
3. Andy, D., Stanley, W., Environmental Hydrology, $2^{\text {nd }}$ ed., Boca Raton, FL, USA: CRC Press, 2004.

4. Bedient, P., Huber, W., Hydrology of Floodplain Analysis, 2nd ed., New York, USA: AddisonWesley, 1992.

5. Chow, V. T., Maidment, D., Mays, L., Chow, V. T., Applied Hydrology, Austin, TX: McGraw-Hill, 1988.

6. De Smedt, F., Yongbo, L., \& Gebremeskel, S., Hydrologic Modelling on a Catchment Scale using GIS and Remote Sensed Land use Information. In C. A. Brebbia (Ed.), Risk Analysis II. Southampton, Boston: WIT press, 2000, pp. 295304.

7. Glenn, O., Frevert, R., Kenneth, K., Edminster, T., Elementary Soil and Water Engineering, $3^{\text {rd }}$ ed., New York: John Wiley, 1985.

8. Kumar, D., Sathish, S., "River Flow Forecasting using Recurrent Neural Networks". Journal of Water Resources Management, Vol. 18, No. 02, 2004, pp. 143-161.

9. Liu, Y. B., Gebremeskela, S., De Smedt, F., Hoffmannb, L., Pfisterb, L., “A Diffusive Transport Approach for Flow Routing in GISBased Flood Modeling". Journal of Hydrology, Vol. 283, 2003, pp. 91-106.

10. Liu, Y. B., Gebremeskela, S., De Smedt, F., Hoffmannb, L., Pfisterb, L., "Predicting Storm Runoff from Different Land use Classes using a Geographical Information System-Based Distributed Model". Hydrological Processes, Vol. 20, 2003, pp. 533- 548.

11. Naden, P., "Spatial Variability in Flood Estimation for Large Catchments: The Exploitation of Channel Network Structure". Hydrological Sciences, Vol. 37, No. 01, 1992, pp. 53-71.

12. Wijesekera, N.T.S., "Parameter Estimation in Watershed Model: A Case Study Using Gin Ganga Watershed, Transactions". Annual Sessions of the Institution of Engineers, Sri Lanka, October 2000.

13. Wijesekera, N.T.S., Abeynayake, J.C., "Watershed Similarity Conditions for Peakflow Transposition - A Study of River Basins in the Wet Zone of Sri Lanka". Engineer Journal of the Institution of Engineers, Sri Lanka, April 2003. 